\title{
Coğrafi Bilgi Sistemleri (CBS) İle İlçeler Düzeyinde Kırsallık Kademelerinin Hazırlanmasına Yönelik Bir Yöntem Önerisi
}

\author{
Çiğdem ÇÖREK ÖZTAŞ ${ }^{1 *}$, Şule KARAASLAN ${ }^{2}$ \\ ${ }^{1}$ Gazi Üniversitesi, Mimarlık Fakiltesi, Şehir ve Bölge Planlama Bölümü, Ankara \\ (cigdemcorek@hotmail.com) ORCID ID 0000-0001-7744-2323 \\ ${ }^{2}$ Gelişim Üniversitesi, Mimarlık Fakültesi, Mimarlık Bölümü, İstanbul \\ (hskaraaslan@gelisim.edu.tr) 0000-0003-0149-9790
}

\begin{abstract}
Öz
Kentsel ve kırsal alanlarda ortaya çıkan değişiklikleri anlama, takip etme ve planlama çabalarının bir sonucu olarak özellikle 2000 li yıllarla birlikte Coğrafi Bilgi Sistemi (CBS) teknolojisi kullanılmaya başlanmıştır. CBS çeşitli verilerin bütünleştirilmesini ve planlamasını sağlayarak kentsel ve kırsal alanların sınıflandırılması ve planlanması aşamalarında önemli bir araç işlevi görebilir. Bu çalışmanın da konusu olan kırsal alanlar üzerinde baskı gün geçtikçe artmakta, kır ve kırsal alan sınıflandırmaları da değişikliğe uğramaktadır. Türkiye'de genel eğilime ek olarak 2012 yılında yürürlüğe giren 6360 Sayılı Kanun ile birlikte, yerel yönetim sistemi köklü değişimlere sahne olmuştur. Kanun'la büyükşehir belediyesi sayısı 30'a çıkarılmış, büyükşehir belediyelerinde köy tüzel kişiliklerine son verilmiş, köyler mahalle statüsü kazanarak kent sınıflandırması altında tanımlanmış; kır-kent ayrımı ortadan kaldırılmıştır. Bu nedenle, bu çalışmada, büyükşehirler içerisindeki her bir yerleşimin yeknesak bir bütün olmadığı; içerisinde kentsel alanlar ve farklı düzeylerde kırsal alanlar barındırdığı ilçe düzeyinde ortaya konmaktadır. Bu çalışma, 30 büyükşehir kapsamında ve 519 ilçede ilk kez ilçe düzeyinde verilerle, yerleşimlerin farklı niteliklerini ortaya koymak üzere Coğrafi Bilgi Sistemleri (CBS) kullanılarak analiz çalışması gerçekleştirilmiş öncü bir çalışmadır.
\end{abstract}

Anahtar Kelimeler: Coğrafi Bilgi Sistemleri, Büyükşehir Belediyeleri, Kırsal Alan.

\section{A Methodology Proposal To The Preparation Of Levels Of Rurality in District Level By Using Geographical Information Systems (GIS)}

\begin{abstract}
Geographic Information System (GIS) technology has begun to be used as a result of efforts to understand, track and plan changes in urban and rural areas, especially in 2000s. GIS can serve as an important tool in the classification and planning of urban and rural areas by providing integration and planning of various data. The pressure on the rural areas, which is also the subject of this study, is increasing day by day, and the rural and rural area classifications are also changing. In addition to the general tendency, the local administrative system in Turkey has undergone through drastic changes along with Law no 6360 on the establishment of fourteen new metropolitan municipalities, which entered into force in 2012. With the law, the number of the metropolitan municipalities raised to 30 and all the rural areas in 30 metropolitan municipalities have the status of urban, eliminating the rural-urban distinction. For this reason, this study is about how to classify rurality in metropolitan municipalities. In the study, analyses were made in 30 metropolitan cities and 519 districts in these metropolitan municipalities using geographical information systems (GIS).
\end{abstract}

Anahtar Kelimeler: Geographical Information Systems, Metropolitan Municipalities, Rural Area..

* Sorumlu Yazar 


\section{GíRIŞ}

Coğrafi Bilgi Sistemi, grafik ve grafik olmayan verilerin coğrafi koşullar gözetilerek elde edilmesi, depolanması, işlenmesi ve kullanıcıya sunulması işlevlerini bir bütünlük içerisinde gerçekleştiren bir bilgi sistemidir. CBS bünyesinde, coğrafi veri tabanı, yazılım, donanım, personel, standartlar ve yöntemler gibi bileşenleri kapsar. $\mathrm{Bu}$ özelliklerinden dolayı CBS, tüm dünyada çok geniş kullanım alanlarına sahiptir. CBS, farklı ölçeklerde, farklı projeksiyonlardaki haritaların üretiminin yanı sıra, bu haritaların kullanımına yönelik bir analiz sistemi sunduğu için sadece harita üreten bir program olarak değerlendirilmemelidir. Sistemin en büyük avantaj1 ise, harita üzerindeki grafik bilgilerin, birbirleri ile veya kriterler bazında, mekansal ve mantıksal ilişkilerini sunmasıdır (Aydal, 2012). CBS'de katman mantığ1 ile çalışıldığ1 için aynı anda çok farklı konular arasında bağlantı kurulabilmektedir. $\mathrm{Bu}$ nedenle bağlantı kurulan konular arasında sorgulama yapılabilmekte, haritalar aynı ekranda görüntülenebilmekte ve katmanların birbiriyle olan ilişkileri sorgulanabilmektedir (Yomralığlu, 2009). Bunların yanında, CBS sistemleri kullanılarak, mekânsal verinin analizi, gösterimi, çok geniş ölçekteki karmaşık verilerin yönetimi, mekânsal verinin nitel ve doğal olarak ifade edilmesi mümkündür (Elwood, 2010).

Son dönemde, toplumda yaşayan bireylerin yaşam standartlarını artırmak amaciyla özellikle planlama ve yönetim süreçlerinde CBS'nin etkin kullanımına odaklanılmaktadır (Drucker, 2012).

CBS analizleri kullanılarak elde edilen alan kullanım verilerinin nitelik ve niceliğindeki değişimlerin kullanımı da, sürdürülebilir alan kullanım hedeflerine ulaşılmasında öne çıkan önemli araçlardan birisidir (Özyavuz, 2011).

Coğrafi Bilgi Sistemlerinde yaşanan bu gelişmeler, sayısal haritaların kullanım alanını ve oranını giderek arttırmış ve CBS'nin son yüzyılın en önemli bilgi teknolojisi araçlarından birisi olarak tanımlanmasına neden olmuştur. $\mathrm{Bu}$ durum, CBS'nin pek çok kurum ve kuruluş tarafindan kullanılmasını sağlamıştır. Çok sayıda veri ve bilginin yönetimi, analizi, sayısallaştırılması ve görselleştirilmesi gibi çok önemli araçlar barındıran CBS bu yönüyle konum verilerinin kullanıldığı pek çok planlama çalışmasında da analiz sürecine dahil edilmektedir (Agapiou vd., 2015).

Türkiye'de de Çevre ve Şehircilik Bakanlığı'nda yer alan Coğrafi Bilgi Sistemleri Genel Müdürlüğü bünyesinde bu konuda çalışmalar yürütülmektedir. Çevre ve Şehircilik Bakanlığı'nın yetkili olduğu çevre düzeni planlarının hazırlanmasında CBS teknolojileri kullanılmaktadır. Bunun yanında, Kalkınma Bakanlığı ve kalkınma ajanslarınca hazırlanan bölge planlarında ve ilgili belediyeler tarafindan hazırlanan ulaştırma master planları gibi üst ölçek planlarda da CBS teknolojilerinden yararlanılmaktadır.

$\mathrm{Bu}$ çalışmanda ise 30 büyükşehir belediyesinde yer alan 519 ilçenin kırsallık kademelenmesini tespit etme sürecinde coğrafi bilgi sistemlerinden yararlanılmıştır.

Türkiye'de dünyadaki gelişme eğilimine paralel olarak 1950'lerden başlayan hızlı bir kentleşme süreci yaşanmıştır. 1980'lere kadar kentli nüfus artışı kırsal nüfusu azınlığa düşürmüş, sonrasında ise toplam nüfus içindeki kentsel nüfus oranı giderek artmıştır. 2012 y1lında yürürlüğe giren 6360 sayılı "On Dört İlde Büyükşehir Belediyesi ve Yirmi Yedi İlçe Kurulması ile Bazı Kanun ve Kanun Hükmünde Kararnamelerde Değişiklik Yapılmasına Dair Kanun" ile Büyükşehir Belediyelerinde köylerin mahalle statüsü kazanması neticesinde ise kentsel nüfus oranı \%92'ye ulaşmış, böylece kentsel alanların kırsal alanlar üzerindeki baskısı giderek artmıștır. Kanunla birlikte, Büyükşehir olmayan 51 ilde, nüfusu 2.000 kişinin altındaki belde belediyelerinin tüzel kişiliğine son verilmekte, 30 büyükşehirde toplam 10.243.502 kişilik köy halkının anayasal güvenceleri sona ermektedir. Yasadaki değişiklikle birlikte ilçeler ve köyler büyükşehir belediyesi sınırları içinde kalmış ve 
tüm il kentsel alan olarak kabul edilmiş, kırsal ayrımı ise kaldırılmıştır (6360 Sayılı Kanun, Md.1, 2012).

Yeni durumda, statüsü kent olan ancak karakteri kırsal özellikler gösteren bir yapılanma biçimi ortaya çıkmıştır. $\mathrm{Bu}$ yeni düzenleme ile birlikte büyükşehirlerde mekânsal özellikler açısından her bir alanın aynı kabul edilmesi, kentsel ve kırsal alanlar için pek çok sorunu da beraberinde getirmektedir.

Mevcut durumda, mahalle statüsü kazanmış eski kırsal alanların siniflandırılmasına ve planlamasina dair mevcut imar mevzuatı ve planlama pratiği yetersiz ve belirsiz kalmaktadır. Gerek 3194 Sayılı İmar Kanunu gerekse Mekânsal Planlar Yapım Yönetmeliği kent statüsü kazanan kırsal alanların farklı niteliklerini gözardı ederek bu alanların planlamasına dair herhangi bir çözüm önerisi geliştirmemiştir.

2014-2018 yıllarını kapsayan X. Beş Yıllık Kalkınma Planında "kırsal alan tanımı revize edilecek, temel nitelikteki ulusal verilerin kırkent ve il bazında yayımlanması sağlanacaktır ifadesine yer verilmiştir (Kalkınma Bakanlığı, 2013). 2014-2020 y1llarını kapsayan ikinci Ulusal Kirsal kalkınma Stratejisinde de mahalle statüsü kazanan köyler ve beldeler nedeniyle ülke geneli için yeni bir kırsal tanımı getirilmesi gerektiği belirtilmektedir (G1da, Tarım ve Hayvancılık Bakanlı̆̆ı, 2015).

$\mathrm{Bu}$ plan ve stratejilerden de görüleceği gibi, Türkiye'de büyükşehir belediyelerinde kırsal alanine belirlenmesine ve tanımlanmasına dair bir boşluk bulunmakta ve bu konuya yönelik yeni bir yaklaşım arayışı bulunmaktadır.

$\mathrm{Bu}$ nedenle bu çalışmada, büyükşehirler içerisindeki her bir yerleşimin yeknesak bir bütün olmadığı; içerisinde kentsel alanlar ve farklı düzeylerde kırsal alanlar barındırdığı ortaya koymak; kanunun yarattığı bu tanımsızlığı gidermek ve kentsel/kırsal sınıflandırmasının nasıl yapılabileceğine dair yön göstermek amaciyla Coğrafi Bilgi Sistemleri (CBS) kullanılarak bir analiz süreci takip edilmiştir.

\section{YÖNTEM}

\section{1. İlgili Kaynaklardan Verilerin Temini}

Coğrafi bilgi sistemleri (CBS) ile ilçeler düzeyinde kırsallık kademelerinin hazırlanması sürecinin ilk aşamasını veri temini süreci oluşturmaktadır. Büyükşehir belediyeleri bütününde yer alan yerleşimlerin karakter farklılıklarını ortaya koyabilmek için öncelikle 30 büyükşehir belediyesinde yer alan toplam 519 ilçeye dair:

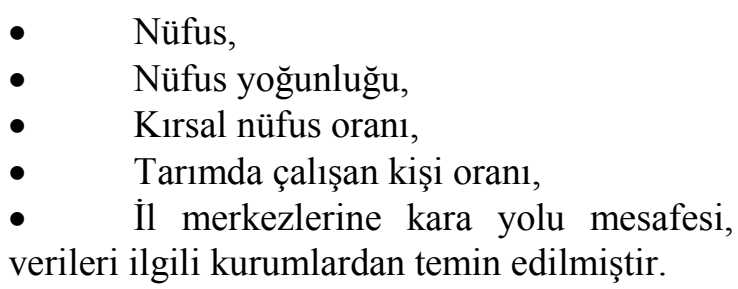

2015 yılına ait nüfus verileri, TÜİK Merkezi Dağıtım Sisteminden ilçe düzeyinde temin edilmiştir. Daha sonra nüfus verilerinin ilçe yüz ölçümlerine oranı bulunarak ilçe nüfus yoğunlukları hesaplanmış ve çeşitli kaymakamlık sitelerinde yayınlanan ilçe nüfus yoğunlukları ile karşılaştırma yapılarak verilerin güvenilirliği test edilmiştir. İlçe yüz ölçümleri ise Harita Genel Komutanlığı İlçe Alan Verilerinden elde edilmiştir.

2012 yılında 6360 Sayılı Kanunun yürürlüğe girmesiyle birlikte nüfus verileri hesaplanırken kırsal nüfus ve kentsel nüfus ayrımı yapılmamaktadır. Bu çalışmada kentsel nüfusa oranının hesaplanması çalışma açısından önem arz ettiği için, kırsal nüfus oranı verisinin temini sürecinde kırsal nüfusun en son hesaplandığ 1 yıl olan TÜİK 2012 nüfus verileri kullanılmıştır. İlçelerin kırsal nüfus oranlarını bulmak amaciyla her bir büyükşsehirde yer alan ilçelere dair kırsal nüfus ve toplam nüfusları bir tablo haline getirilmiş ve buradan kırsal nüfusun toplam nüfusa oranı bulunmuştur. $\mathrm{Bu}$ veriler temin edilirken de yine nüfus verilerinin çevrim içi olarak yayınlandığ 1 TÜİK Merkezi Dağıtım Sistemi kullanılmıştır. 
Tarımda çalışan kişi oranı da analiz sürecinde kullanılan bir diğer değişkendir. Bu değişken ise Sosyal Güvenlik Kurumu Sigorta Primleri Genel Müdürlüğü Risk Yönetimi ve Proje Daire Başkanlığı'ndan temin edilmiştir. Tarımda çalışan kişi alt kırılımlarını ise,

- $\quad$ NACE-A-01-bitkisel ve hayvansal üretim/avcılık,

- NACE-A-02-ormancilik ve A-03 balıkçılık,

- $\quad$ NACE-Su ürünlerine kayıtlı çalışan say1s1,

- $\quad$ İlçelerde kayıtlı toplam çalışan sayısı oluşturmaktadır.

Analizlerde kullanılan bir diğer değişken ise il merkezlerine olan karayolu mesafesidir. İlçelerin il merkezlerine uzaklıkları değişkenine ulaşmak amacıyla, "Karayolları Genel Müdürlüğü'ne ait İlçelerin İl Merkezine Olan Karayolu Uzaklıkları" verisi kullanılmıştır.

Son olarak, verilerin mekânsallaştırılması aşamasında kullanılmak üzere Türkiye'de yer alan illere ve ilçelere dair koordinatlı güncel konumsal veriler Kalkınma Bakanlığı'ndan temin edilmiştir.

Değişkenlerin, coğrafi bilgi sistemleri ortamında analiz edilebilmesi için, illere ve ilçelere dair veri tabanının yer aldığı Arc Map haritasıyla eşlenecek bir excell dosya hazırlanmış; sonrasında oluşturulacak katmanlara göre bu excel dosyas1 ayrıştırılmıştır. $\mathrm{Bu}$ dosyada, harita veri tabanında bulunan ve bu altlık veri ile eşleşmesini sağlayacak olan her bir ilçenin:

- ID (kimlik) numaralarına,

- 30 büyükşehir belediyesi isimlerine,

- $\quad 519$ ilçe ismine,

- $\quad$ İlçelerin 2015 nüfuslarına,

- İlçelerin 2012 yılı kırsal nüfus oranlarına,

- 2015 y1lı tarımda çalışan kişi oranlarına,
- İlçelerin merkeze olan karayolu mesafelerine,

- $\quad$ İlçelerin 2015 nüfus yoğunluklarına,

Yer verilmiştir.

\subsection{Sözel Verilerin Vektör Veriler ile İlişkilendirilmesi}

Coğrafi bilgi sistemleri (CBS) ile ilçeler düzeyinde kırsallık kademelerinin hazırlanması sürecinin ikinci aşamasında, temin edilen veriler Arcgis sistemine aktarılarak sözel veriler vektör veriler ile ilişkilendirilmiştir. $\mathrm{Bu}$ aşamada izlenen yöntem şu şekilde açıklanabilir:

Öncelikle her bir verinin yer aldığ dosyaları join (birleştir) ve relate (ilişkilendir) komutları kullanılarak konumsal verilerle eşleştirilmiştir.

$\mathrm{Bu}$ aşama sonrasında Arcmap arayüzü açılmış ve add data (veri ekle) komutu kullanılarak önce ilçe ana verisi, sonrasında ise aynı işlem uygulanarak il sinırları verisi Arcmap ortamına eklenmiştir.

Arcmap ortamında sadece koordinat tabanl olan ilçelere verilerin eklenmesi amaciyla ilçe katmanına sağ tıklanarak join (birleştir) ve relate (ilişkilendir) komutları birlikte kullanılmıştır. Böylece ilçe sözel verileri ile vektör veriler ilişkilendirilmiştir. $\mathrm{Bu}$ işlem nüfus, nüfus yoğunluğu, kırsal nüfus oranı, tarımsa istihdam oran1, merkeze karayolu mesafesi verileri için ayrı ayrı yapılmış ve oluşturulan her katman, ilişkilendirilen verinin türüyle isimlendirilmiştir.

\subsubsection{Nüfus Verisi}

$\mathrm{Bu}$ bölümde, TUíK Merkezi Dağıtım Sisteminde yayınlanan 2015 yılı ilçe nüfus büyüklük verileri 30 büyükşsehir belediyesinde yer alan 519 ilçe düzeyinde işlenmiş ve haritalanmıştır (ADNKS, 2015). 
$\mathrm{Bu}$ aşamada Arcgis ortamında oluşturulan altlık harita kullanılarak; bu haritaya 2015 yılı ilçe nüfus bilgileri verisi eşleştirilmesi ile sonuca varılmıştır. Arcmap ortamında sadece koordinat tabanlı olan ilçe verilerine, ilçe katmanına sağ tıklanarak ve join (birleştir) ve relate (ilişkilendir) komutları birlikte kullanılarak ilçelerin szöel verileri vektörel veriler ile ilişkilendirilmiştir. Çıkan ekrandan ilgili dosya seçilmiştir.

Verinin doğru ilçe ile eşleşmesinin sağlanması için excel dosyasında nüfus bilgisi yanında yer alan ve her bir ilçe için oluşturulmuş olan, ilçelerin kimlik numaraları olarak da adlandırılabilecek ID (kimlik) numaraları ile
Arcmap dosyasının yine her bir ilçe için atadığı OBJECTID eşleşmesi sağlanmıştır.

Validate Join (doğrulama) komutu kullanılarak verilerin eşleştiğinden emin olunmuştur.

İlçelerle eşleştirilmiş olan veriler, haritada gösterilmek üzere sınıflandırılmıştır. $\mathrm{Bu}$ kısımda, Arcmap dosyasına eklenmiş olan ilçe nüfus verisi katmanına sağ tıklanarak layer properties (katman özellikleri) özelliği açılmış ve buradan symbology (semboloji) > Quantities (nicelik)>dot density (nokta yoğunluğu) komutları seçilerek ve her bir nokta 2000 kişiyi temsil edecek şekilde düzenlenmiştir.

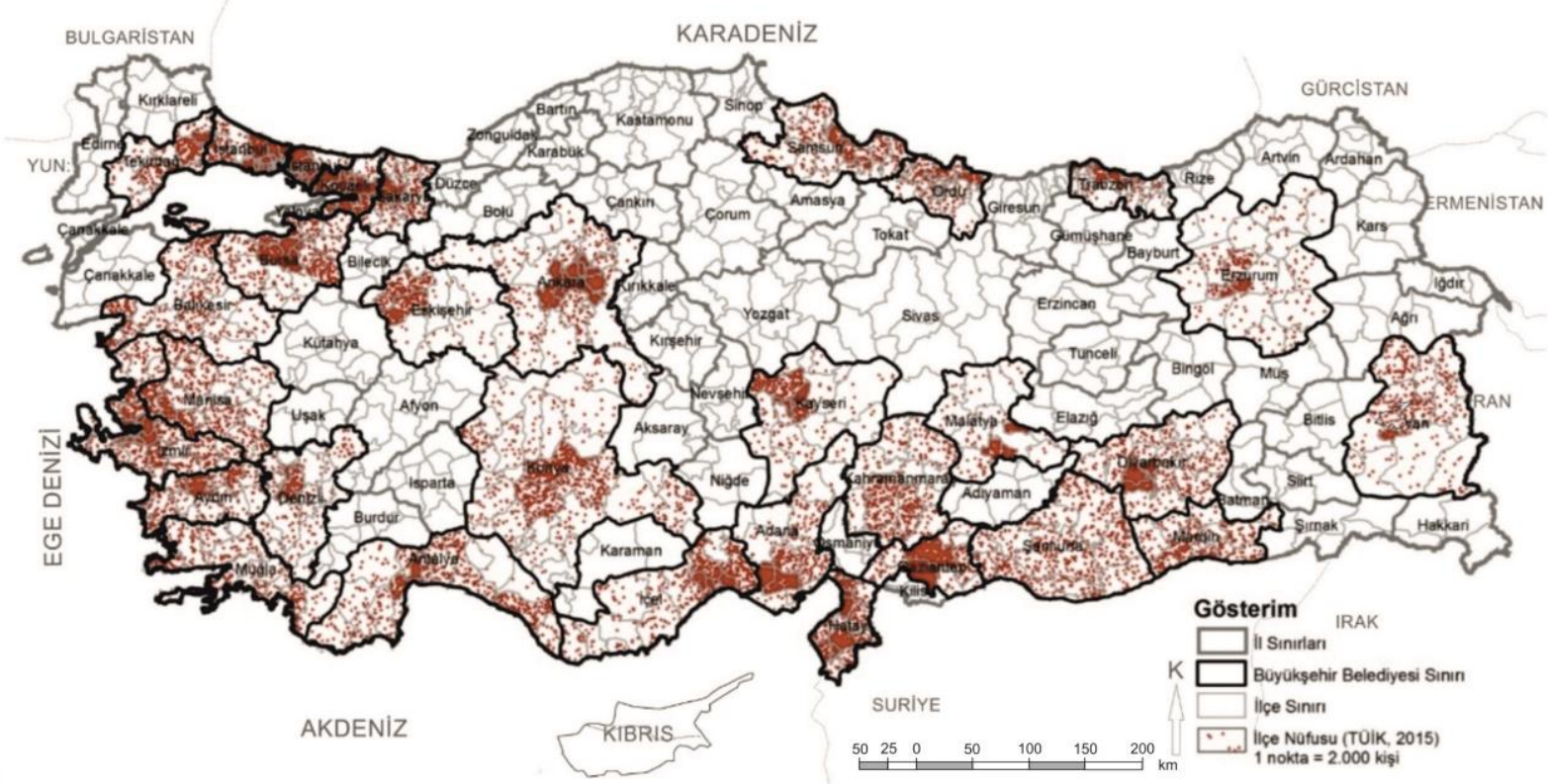

Şekil.1. 2015 Nüfus büyüklüğüne göre nokta yığılma haritası, (Yazar tarafından hazırlanmıştır)

\subsubsection{Nüfus Yoğunluğu Verisi}

Türkiye yerleşim yapısını daha iyi yansıtması ve Türkiye'nin de bir Ekonomik İşbirliği ve Kalkınma Örgütü (OECD) üyesi ülke olmas1 sebebiyle burada OECD kırsal/kentsel ayrımında kullanılan kriter olan $150 \mathrm{kişi} / \mathrm{km}^{2}$ değeri değerlendirmeye alınarak bir sınıflandırma gerçekleştirilmiştir. OECD'ye göre yerleşimin $150 \quad \mathrm{kişi} / \mathrm{km}^{2}$ yoğunluk değerinin üzerinde olma durumu kentsel alan; 
altında kalma durumu ise kırsal alanı ifade etmektedir (OECD, 2006).

Verilerin temini sürecinin ardından (TUİK, 2015-Harita Genel Komutanlığ İlçe Alan Veri si) her bir ilçeye atanan kimlik (ID) numaralarını da içeren bir excel dosyası hazırlanmıştır. Daha sonra Arcmap arayüzü açılmış; add data (veri ekle) komutu kullanılarak ilçe ana verisi Arcmap ortamına eklenmiştir. 2015 y1lı ilçe nüfus yoğunluğu verisi, Arcmap ortamında oluşturulan ilçe OECD katmanı ile eşleştirilmek için, bu katmana sağ tıklanarak ve join (birleștir)-relate (ilişkilendir) komutları kullanılmıştır.

Nüfus yoğunluğu excel dosyasına tanımlanmış ID numaraları ile Arcmap dosyasının bir ilçe için atadığ 1 OBJECTID eşleşmesi sağlanmıştır.

Verilerin sinıflandırılarak mekânda gösterilmesi işlemi içinse, oluşturulan katmana sağ tıklanarak properties (özellikler) komutu seçilmiş; daha sonra, Quantities (nicelik)> graduate colors (dereceli renklendirme)> Values (değer) komutları kullanılarak nüfus yoğunluğu dosyası seçilmiştir.

Classification (siniflandırma) komutu kullanılarak $150 \mathrm{kişi} / \mathrm{km}^{2}$ sınırının altı ya da üstü değer alan ilçeler sınıflandırılacağından classes (siniflar) sekmesine "2" rakamı yazılmış, yoğunluk değerlerine göre en yoğun iki kategori işaretlenmiştir.

$\mathrm{Bu}$ aşamayı takiben, yine layer properties (katman özellikleri) penceresinde sınıflandırması yapılmış değer aralıklarının gösterimde görülmesi istenen değeri ve renkleri belirlenmiştir. Tüm bu işlemlerin ardından $150 \mathrm{kişi} / \mathrm{km}^{2}$ kırılımına göre nüfus yoğunluğuna göre ilçeler haritası hazırlanmıştır (Şekil.2).

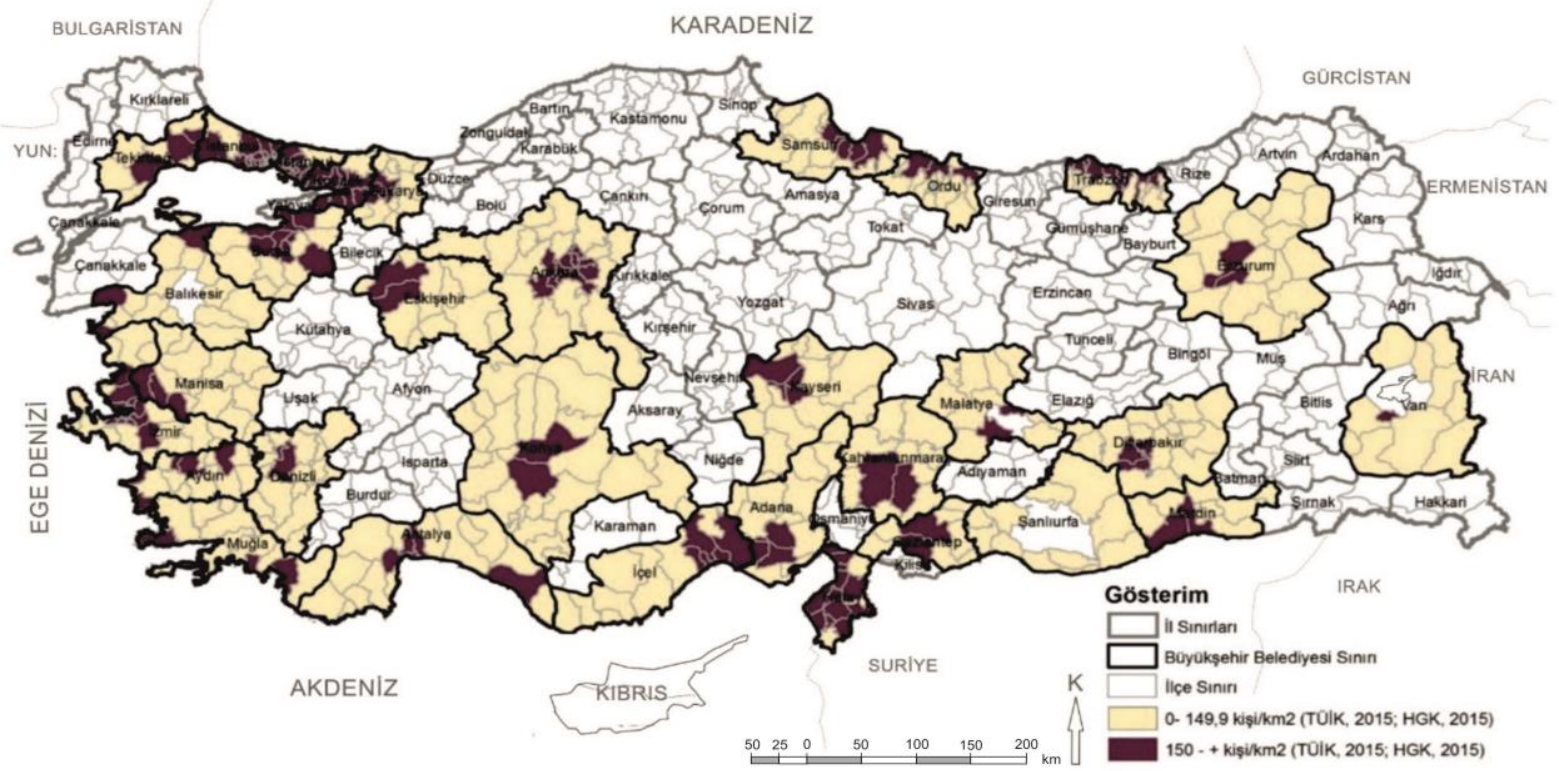

Şekil.2. Nüfus yoğunluğun göre ilçeler (Yazar tarafından hazırlanmıştır) 


\subsubsection{Kırsal nüfusun toplam nüfus içindeki payı verisi}

OECD bölgesel düzeyde yapılan kırsal alan sınıflandırmalarında üç kategori kullanmaktadır. Buna göre bir bölge:

- $\quad$ Nüfusun $\% 50$ 'den fazlasinın kirsal alanlarda yaşaması durumunda baskın kırsal bölge,

- Nüfusun \%15 ile \%50 arasındaki kısmının kırsal alanlarda yaşaması durumunda orta düzeyde kırsal bölge,

- Nüfusun \%15'ten azının kirsal alanlarda yaşaması durumunda ise baskın kentsel bölge,

Olarak tanımlanmaktadır (OECD, 2006).

$\mathrm{Bu}$ çalışmada da kırsal nüfus oranının sinıflandırılması sürecinde OECD değerleri kullanılmıştır.

İlçelere ait kırsal nüfus oranlarının saptanmasının ardından, 2012 y1lı kırsal nüfusun toplam nüfus içindeki payı verisi, Arcmap ortamında oluşturulan katman ile eşleştirilmiştir.

Verilerin sinıflandırılarak mekânda gösterilmesi işlemi için, oluşturulan katmana sağ tıklanarak properties (özellikler) komutu seçilmiş, daha sonra, quantities (nicelik)> graduate colors (dereceli renklendirme)> Values (değer) komutları kullanılarak kırsal nüfus oran1 dosyası seçilmiştir. Ekranda karşımıza çıkan sınıflandırılmamış değerleri sınıflandırabilmek için classify (sınıflandırma) komutu seçilerek burada OECD sinıflandırmasına göre belirlenen $\% 15$ alt1; $\% 15$ ve $\% 50$ aralığı; \%50 fazlası aralıklarının oluşturulabilmesi için classes (sınıflar) sekmesine "3" rakamı yazılmış break values (kırılma değerleri) Şekil.3’te de görüldüğü gibi buna göre şekillendirilmiştir.

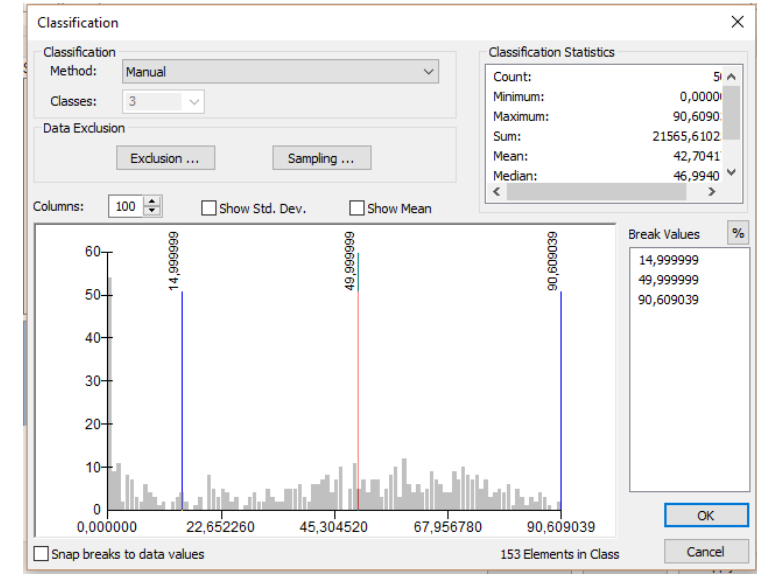

Şekil.3. Kırsal Nüfus Oranı Verisinin

Sinıflandırılması

Daha sonra son aşamaya geçilmiş ve layer properties (katman özellikleri) ekranında artık sınıflandırılmış olan değerler ortaya çıkmıştır. Symbol (sembol) bölümünde yer alan kutucukların renkleri üzerlerine tıklanarak belirlenmiş; label (etiket) bölümünde yer alan sınıflandırılmış değerler de gösterimde görülmesi istenen şekilde düzenlenmiştir. Tüm bu işlemlerin sonucunda Şekil.4 hazırlanmıştır. 


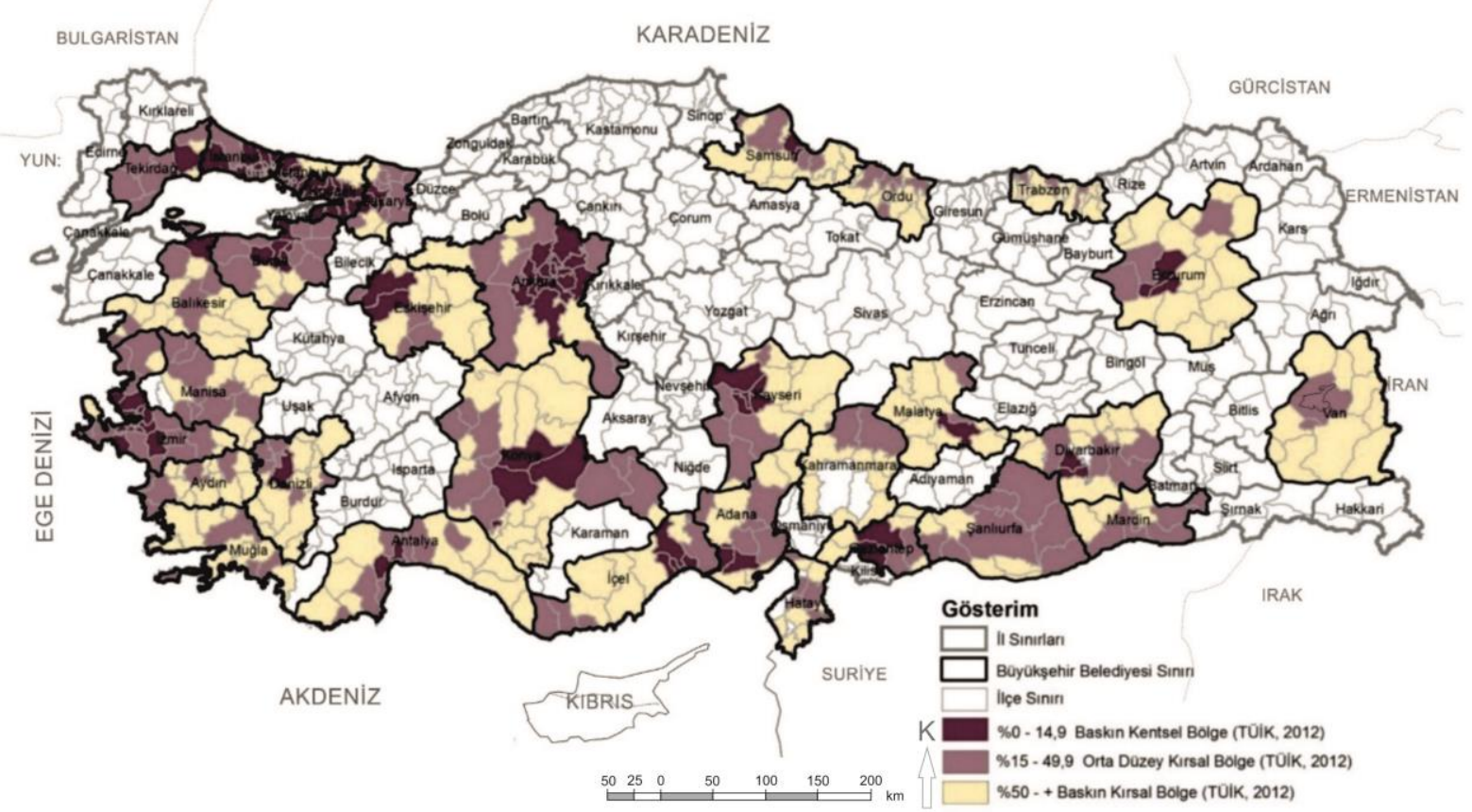

Şekil.4. Kırsal nüfusun toplam nüfusa oranına göre ilçeler

\subsubsection{Kent merkezine karayolu uzaklığı verisi}

AB kırsallık tanımında kırsal olarak nitelenen bir bölgeye yakın kentsel bir alanın varlığ son zamanlarda kirsallik siniflandirmasinda kullanılan bir gösterge halini almıştır. OECD'de de AB'ye benzer biçimde kırsal alan olarak tanımlanmış bir alana yakın kentsel bir alan bulunması kırsallığı etkileyen bir faktör olarak ele alınmıştır (OECD, 2006). Türkiye'de yapılmış kırsallık çalışmalarında da kent merkezine mesafenin bir kirsallık kriteri olarak ele alınmas1; bunun yanında 6360 Sayılı Kanun'la uzaklık yakınlık farkı gözetmeksizin büyükşehirlerin her bir alanına eşit ekonomik, çevresel ve sosyal hizmetler götürüleceği taahhüttü ve bunun gerçekleşemeyeceğine dair eleştiriler dolayısıyla ilçelerin kent merkezlerine $\mathrm{km}$ cinsinden uzaklıkları, ilçelerin kırsallık ve kentsellik düzeylerini anlamaya yardımcı bir gösterge olarak değerlendirilmiştir (6360 Sayılı Kanun, Md.1, 2012).

Öncelikle “Karayolları Genel Müdürlügü’ne ait İlçelerin İl Merkezine Olan Karayolu
Uzaklıkları" verisinden 30 büyükşehir belediyesinde yer alan ilçelerin $\mathrm{km}$ cinsinden kent merkezine uzaklıkları çekilerek ilçelere atanan kimlik (ID) numaralarının da olduğu bir excel tablosuna ișlenmiștir. Add data (veri ekle) komutu kullanılarak mesafe verisi için de Arcmap ortamına ayrı bir katman atanmıştır.

Tüm doğrulama işlemleri yapıldıktan sonra TUiK 2012 yılı kirsal nüfusun toplam nüfus içindeki payı verisi, Arcmap ortamında oluşturulan katman ile eşleştirilmek için, bu katmana sağ tıklanarak ve join (birleştir)-relate (ilişkilendir) komutları kullanılarak bu verilerin ilçe vektörel verileri ile ilişkilendirilmesi sağlanmıştır.

Verilerin sinıflandırılarak mekânda gösterilmesi işlemi için, oluşturulan katmana sağ tıklanarak properties (özellikler) komutu seçilmiş, daha sonra, quantities (nicelik)> graduate colors (dereceli renklendirme)> values (değer) komutları kullanılarak "uzaklık km" dosyası seçilmiştir. Ekranda karşımıza çıkan değerleri sınıflandırabilmek için classify (sınıflandırma) komutu seçilmiş, programın oluşturduğu eşik değerler temel alınarak doğal 
kırılımlara göre bir sınıflandırma yapılmıştır. Şekil.5'te de görüldügüü gibi, 519 ilçe içerisinde il merkezine karayolu mesafesi $1 \mathrm{~km}$ olan ilçeler olduğu gibi $223 \mathrm{~km}$ olan ilçe de bulunmaktadır. Mesafe verisinin ilçeler bazında yoğunluğuna bakıldığında ise (Bkz. Şekil.5) 50 km'ye kadar; 50 ile $100 \mathrm{~km}$ arasında ve $100 \mathrm{~km}$ 'den fazla olmak üzere 3 aralıkta yığılmanın olduğu görülebilmektedir. $\mathrm{Bu}$ nedenle Classes (siniflar) sekmesine " 3 " rakamı yazılmış, break values (kırılma değerleri) Şekil 5'de görüldüğü gibi,

- $\quad 50 \mathrm{~km}$ 'den az,

- $\quad 50 \mathrm{~km}$ ile $100 \mathrm{~km}$ arasinda,

- 100 km'den fazla,

Olmak üzere üç kategoride değerlendirilmiştir.

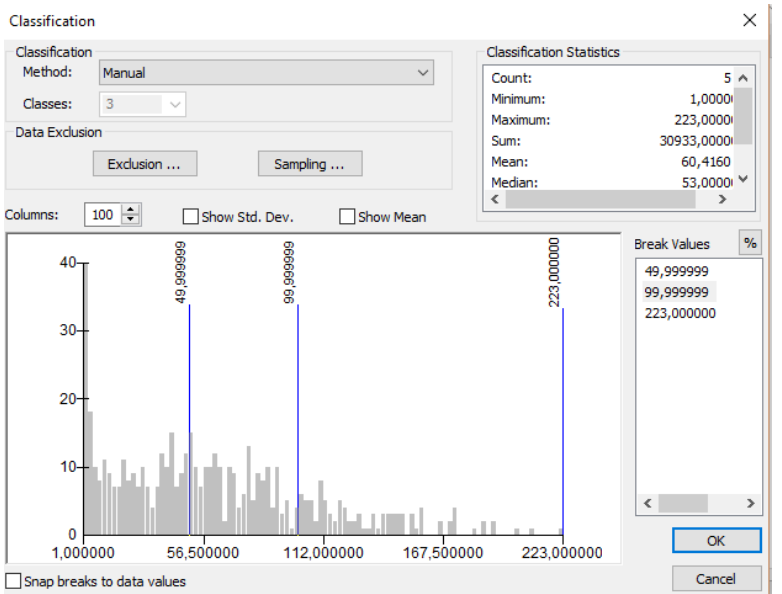

Şekil.5. Merkeze Karayolu Mesafesi Verisinin Sinıflandirılması

Son aşamada ise seçilmiş layer properties (katman özellikleri) ekranında artık sınıflandırılmış olan değerler ortaya çıkmıştır. Symbol (sembol) bölümünde yer alan kutucukların renkleri üzerlerine tıklanarak belirlenmiş; label (etiket) bölümünde yer alan sinıflandırılmış değerler de gösterimde görülmesi istenen şekilde düzenlenmiştir. Apply (uygula) ve ok (tamam) komutları kullanılarak verinin mekânsallaştırılma süreci tamamlanmıştır.

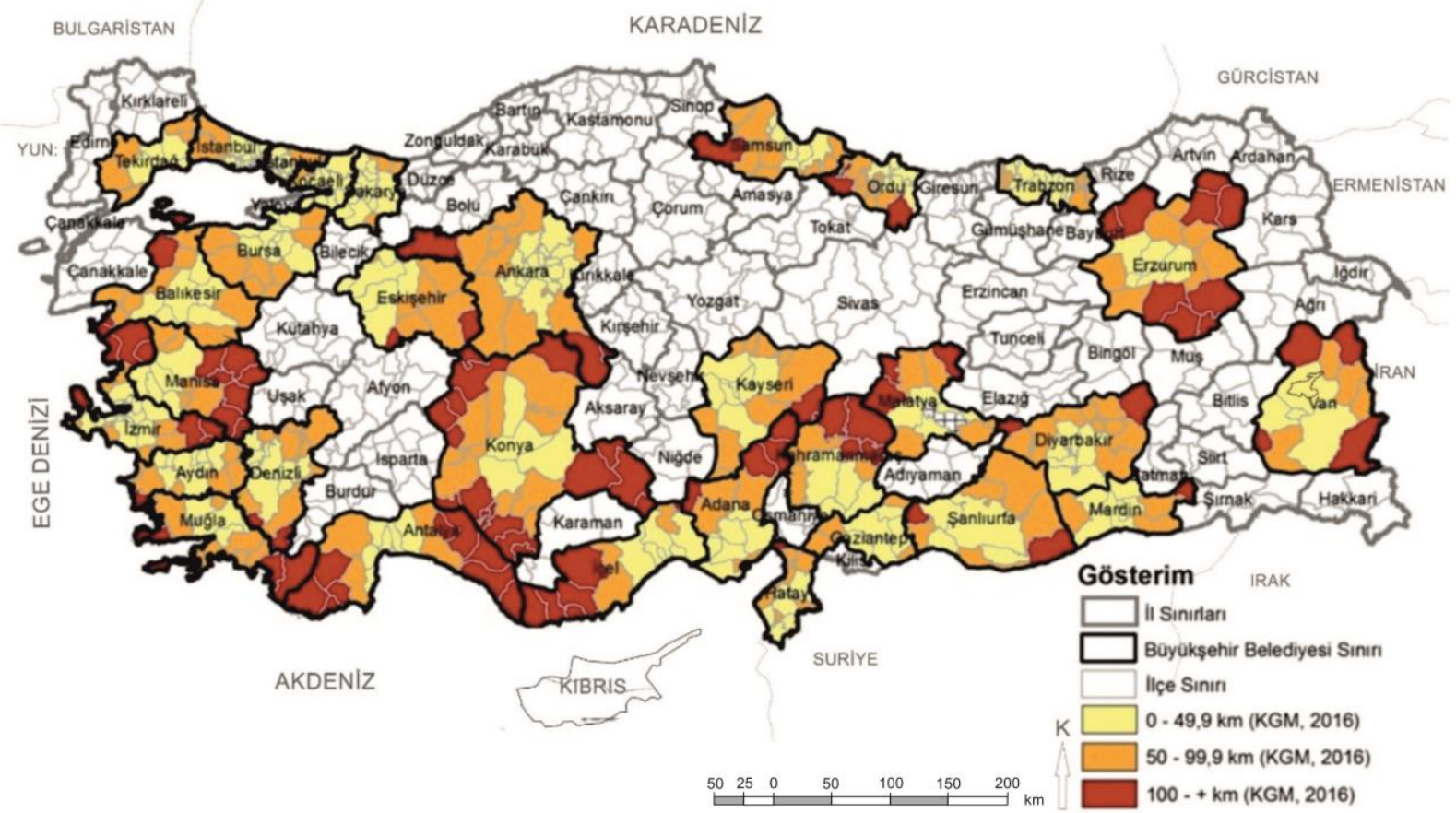

Şekil.6. Merkeze karayolu uzaklığına göre ilçeler 


\subsubsection{Tarımda çalıșan nüfus oranı verisi}

Nüfus yoğunluğu, kırsal nüfus yoğunluğu gibi verilerin kırsallık sinıflandırmasinda yetersiz kalacağı düşünülerek tarım sektöründe çalışan kişilerin toplam çalışan sayısına oranının da değerlendirmeye alınmıştır. Burada tarımda çalışan nüfus, NACE A-01-bitkisel ve hayvansal üretim/avc1lı, A-02-ormanc1lık ve A-03 balıkçılık ve su ürünlerine kayıtlı çalışan sayısıdır. Bu amaçla 2015 yılına ait SGK'ya kayitlı ilçelere göre istihdam verileri temin edilmiştir. Veriler, ilçelere göre tarımda çalışan kişi sayısı ve toplam çalışan sayısı olmak üzere iki kolon halinde excel dosyasına işlenmiş, sonrasında ise tarımda çalışan kişi sayısının toplam çalışan sayısına oranı bulunarak tablo tamamlanmıştır.

Öncelikle diğer veri setlerinde de yapıldığg gibi Arcmap arayüzüne add data (veri ekle) komutu kullanılarak ilçe ana verisi eklenmiştir.

2015 yılı ilçe tarımsal istihdam verisi, Arcmap ortamında oluşturulan katman ile eşleştirilmiştir. Tarımda çalışan nüfus oranı excel dosyasına tanımlanmış ID numaraları ile Arcmap dosyasının bir ilçe için atadığ 1 OBJECTID eşleşmesi sağlanmıştır. Validate Join (doğrulama) komutu kullanılarak verilerin eşleştiğinden emin olunmuş ve verilerin mekâna aktarılması tamamlanmıştır.

Verilerin sinıflandırılarak mekânda gösterilmesi işlemi içinse diğer değişkenlerde yapıldığı gibi properties ve bağlı komutlar kullanılmıştır. Oluşturulan katmana sağ tıklanarak properties (özellikler) komutu seçilmiş, daha sonra, Quantities (nicelik)> graduate colors (dereceli renklendirme)> Values (değer) komutları kullanılarak "tarımsal istihdam" dosyası atanmıştır. Classify (sınıflandırma) komutuna tıklanarak sınıflandırma işlemini gerçekleştirmek üzere doğal eşikler görülmüştür.
Ekranda classes (siniflar) sekmesine "3" rakamı yazılmış ve yoğunluk değerlerine sinıflandırma tamamlanmıştır.

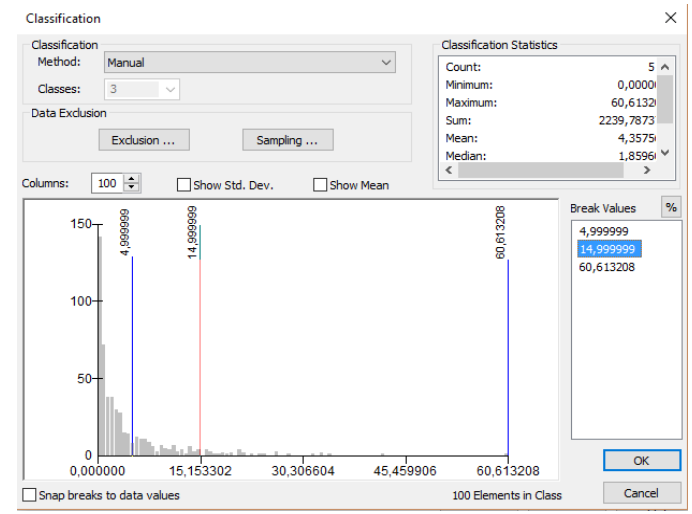

Şekil.7. Tarımda Çalışan Nüfus Oranı Verisinin Sinıflandirılması

$\mathrm{Bu}$ doğal eşikler dikkate alınarak (Şekil 7) veriler tarımsal istihdam oranlarına göre:

$\% 5$ 'in alt1- $\% 5$ ve $\% 15$ aras1- $\% 15$ üzeri, Olmak üzere üç kategoride sınıflandırılmıştır.

Takip eden aşamada, layer properties (katman özellikleri) ekranında artık sınıflandırılmış olan değerler ortaya çıkmıștır. Symbol (sembol) bölümünde yer alan kutucukların renkleri üzerlerine tıklanarak belirlenmiş; label (etiket) bölümünde yer alan sınıflandırılmış değerler de gösterimde görülmesi istenen şekilde düzenlenmiştir. Apply (uygula) ve ok (tamam) komutlar1 kullanılarak verinin mekânsallaştırılma süreci tamamlanmıştır (Şekil.8). 


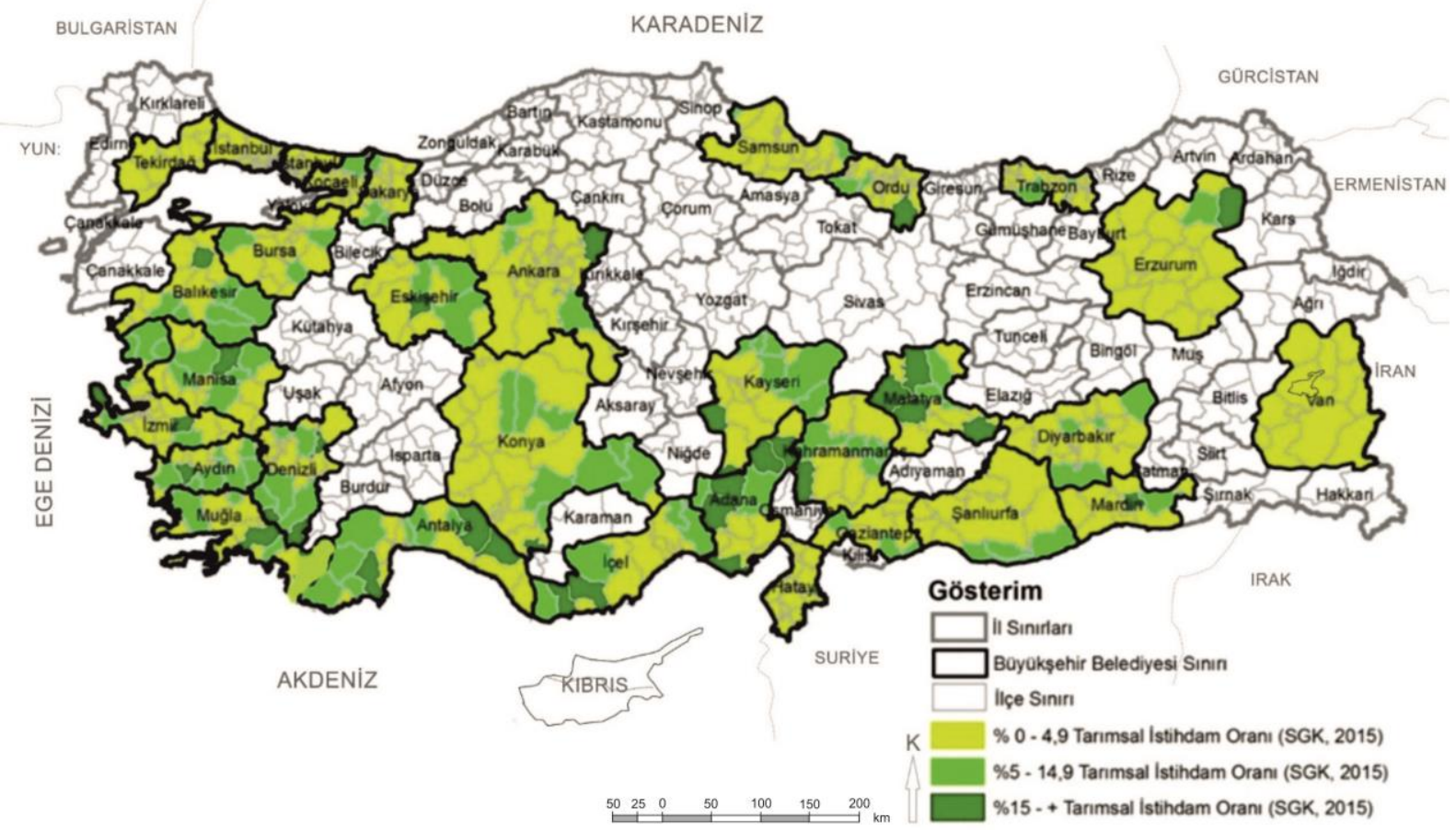

Şekil.8. Tarımda çalışan nüfus oranına göre ilçeler

\section{BULGULAR}

\subsection{Sentez-1: Baskın Kırsal Bölge}

$\mathrm{Bu}$ bölümde,

- Tarımsal istihdam oranının \%15 ve üzerinde olması,

- Nüfusun $\% 50$ ve fazlasının kırsal alanlarda yaşaması (OECD siniflandirmasi),

- Nüfus Yoğunluğunun $150 \mathrm{kişi} / \mathrm{km}^{2}$ nin altında kalması,

- Merkeze olan uzaklığın 100 km ve üzerinde olması,

Değişkenleri bir arada kullanılarak her bir sinıflamaya yönelik sentez analiz gerçekleştirilmiştir.

Yukarıda detayları verilen değişken aralıklarını kullanarak baskın kırsal bölgeleri oluşturan ilçeleri tespit edebilmek için; Arcmap ortamında her bir değişken bu aralıklara göre ayrıştırılmış ve ilgili değişken aralıkları üst üste getirilerek, bu dört özelliği de barındıran ilçeler bulunmuştur. Uygulanan yöntemi daha detaylı anlatmak gerekirse değişkenlere göre belirlenen aralıkların nasil birbirinden ayrıştırıldığına bakmak gerekmektedir.

Tarımsal istihdam verisinde kullanılan üç kategoriden $\% 15$ ve üzeri tarımsal istihdam oranına sahip ilçeleri seçebilmek amacıyla, ana menüde yer alan selection (seçim), sonrasında select by attributes (özelliklerine göre seç) komutları kullanılmıştır. Şekil 9'da da görüldüğü gibi açılan ekranda layer (katman) kısmında ilçe tarım dosyası; dosya içerisinde tarımda çalışan oranı seçilmiş daha sonra get unique values (özgün değerler elde et) komutu seçilerek büyüktür ve eşittir $>=15$ değeri girilmiştir. Verify (doğrula) komutu seçilerek veri doğrulanmış apply (uygula) ve ok (tamam) komutları seçilerek işlem tamamlanmıştır. 


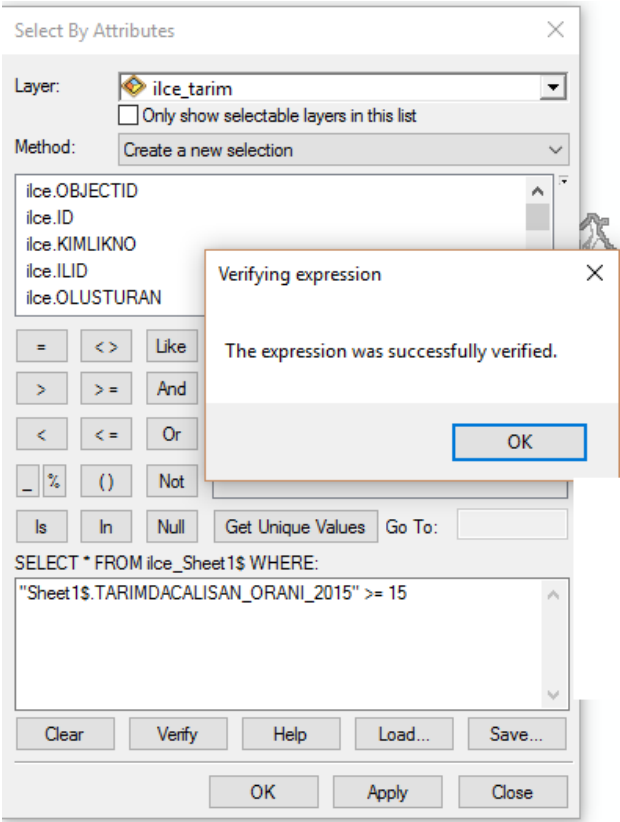

Şekil 9. Tarımsal istihdam verisi baskın kırsal bölge aralıklarının oluşturulması

$\mathrm{Bu}$ işlem sonrasında, tarımsal istihdam oranı $\% 15$ ve üzerinde olan ilçeler seçilmiştir.

"Tarımda Çalışan Nüfus Oranı" başlığ1 dâhilinde oluşturulan ilçe tarım katmanı üzerine sağ tıklanarak açılan pencerede selection (seçim) komutu, buradan açılan pencereden de create layer from selected features (seçilen özelliklerden katman oluştur) komutu seçilmiştir. Yapılan bu işlemler neticesinde $\% 15$ ve üzeri tarımsal istihdam oranına sahip ilçelerle yeni bir katman oluşturulmuştur.

Merkeze karayolu mesafesi değişkeninde de yukarıda izlenen yöntem izlenmiştir. Merkeze karayolu mesafesi verisinde kullanılan üç kategoriden $100 \mathrm{~km}$ ve üzeri uzaklık verisine sahip ilçeleri ayırabilmek amacıyla, ana menüde yer alan selection (seçim), sonrasında select by attributes (özelliklerine göre seç) komutları kullanılmıştır. Açılan ekranda layer (katman) kısmında ilçe mesafe dosyası; dosya içerisinde uzaklık km değeri seçilmiştir. Daha sonra get unique values (özgün değerler elde et) komutu seçilerek büyüktür ve eşittir $>=$ 100 değeri girilmiştir. Verify (doğrula) komutu seçilerek veri doğrulanmış apply (uygula) ve ok (tamam) butonları seçilerek işlem tamamlanmıştır. $\mathrm{Bu}$ işlem sonrasında, merkeze karayolu mesafesi $100 \mathrm{~km}$ ve üzerinde kalan ilçeler seçilmiştir.

Daha sonra, uzaklık katmanına sağ tıklanarak açılan pencerede selection (seçim) butonu, buradan açılan pencereden de create layer from selected features (seçilen özelliklerden katman oluştur) komutu seçilmiş ve $100 \mathrm{~km}$ ve üzerinde merkeze karayolu mesafesine sahip ilçelerden ayrı bir katman oluşturulmuştur.

$\mathrm{Bu}$ iki değişken için takip edilen yöntem, OECD sınıflandırması kapsamında kullanılan kırsal nüfus oranı için de gerçekleştirilmiştir. Ana menüde yer alan selection (seçim), sonrasinda select by attributes (özelliklerine göre seç) komutları kullanılarak açılan ekranda layer (katman) kısminda ilgili dosyalar seçilmiştir. Daha sonra get unique values (özgün değerler elde et) komutu seçilerek büyüktür ve eşittir $>=50$ değeri girilmiştir. Verify (doğrula) komutu seçilerek veri doğrulanmış apply (uygula) ve ok (tamam) komutları seçilerek işlem tamamlanmıştır (Şekil 10).

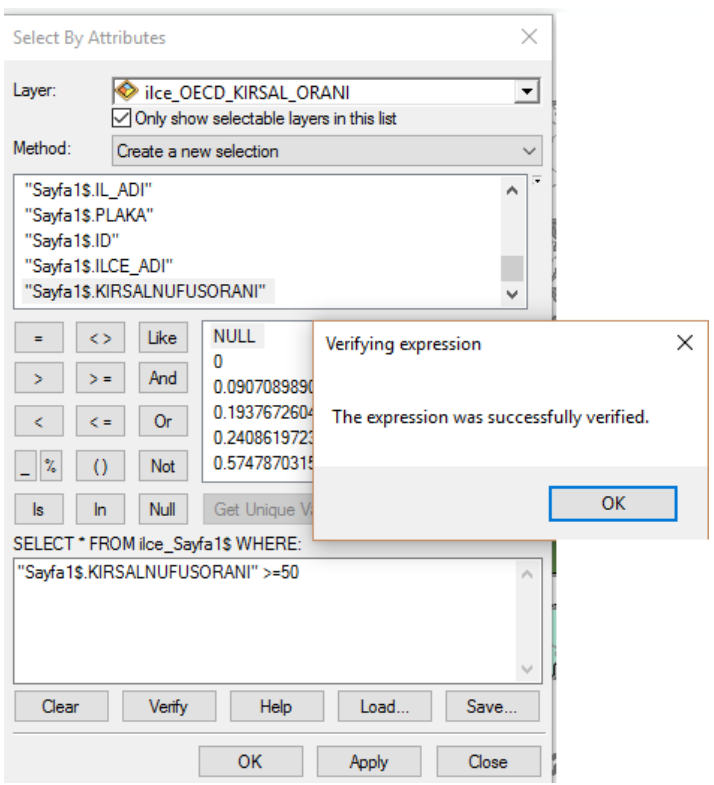

Şekil 10. Kırsal nüfus oranı verisi baskın kırsal bölge aralıklarının oluşturulması

$\mathrm{Bu}$ işlem sonrasında, kırsal nüfus oranı $\% 50$ ve üzerinde olan ilçeler seçilmiştir. 
Daha sonra, kırsal nüfus katmanına sağ tıklanarak açılan pencerede selection (seçim) komutu, buradan açılan pencereden de create layer from selected features (seçilen özelliklerden katman oluştur) komutu seçilmiş ve $\% 50$ ve üzerinde kırsal nüfus oranına sahip ilçelerden ayrı bir katman oluşturulmuştur.

Son olarak aynı işlemler dördüncü değişken olan nüfus yoğunluğu için de uygulanmış; 150 $\mathrm{kişi} / \mathrm{km} 2$ altında olan nüfus yoğunluğuna sahip ilçeler belirlenmiştir.

Baskın kırsal bölge sentez haritasını oluşturmak için yukarıda sıralanan dört değişkenin ayrı ayrı yer aldığı katmanlar, yeni açılan bir başlık altına sürüklenerek bu başlık altında toplanmıştır. Bu katmanlar, ekranda aynı anda açılmış ve üst üste çakışmaları sağlanmıştır.

Tüm bu aşamaların sonucu olarak Harita 6 . baskin kirsal bölge sentez haritas1 oluşturulmuştur. Şekil.11'de görüleceği gibi bu dört değişkenin de bir arada bulunduğu, yukarıdaki değişkenlerin yer aldığı ve baskın kırsal bölge tanımlaması altına giren, 30 büyükşsehir belediyesi genelinde toplam 13 ilçe bulunmaktadır. Bu ilçeler:

\section{Manisa: Gördes}

İzmir: Karaburun

Denizli: Çameli, Beyağaç

Antalya: Akseki, Gündoğmuş

Adana: Feke, Saimbeyli

Malatya: Darende

Ordu: Mesudiye

Erzurum: Şenkaya

Olarak sıralanmaktadır.

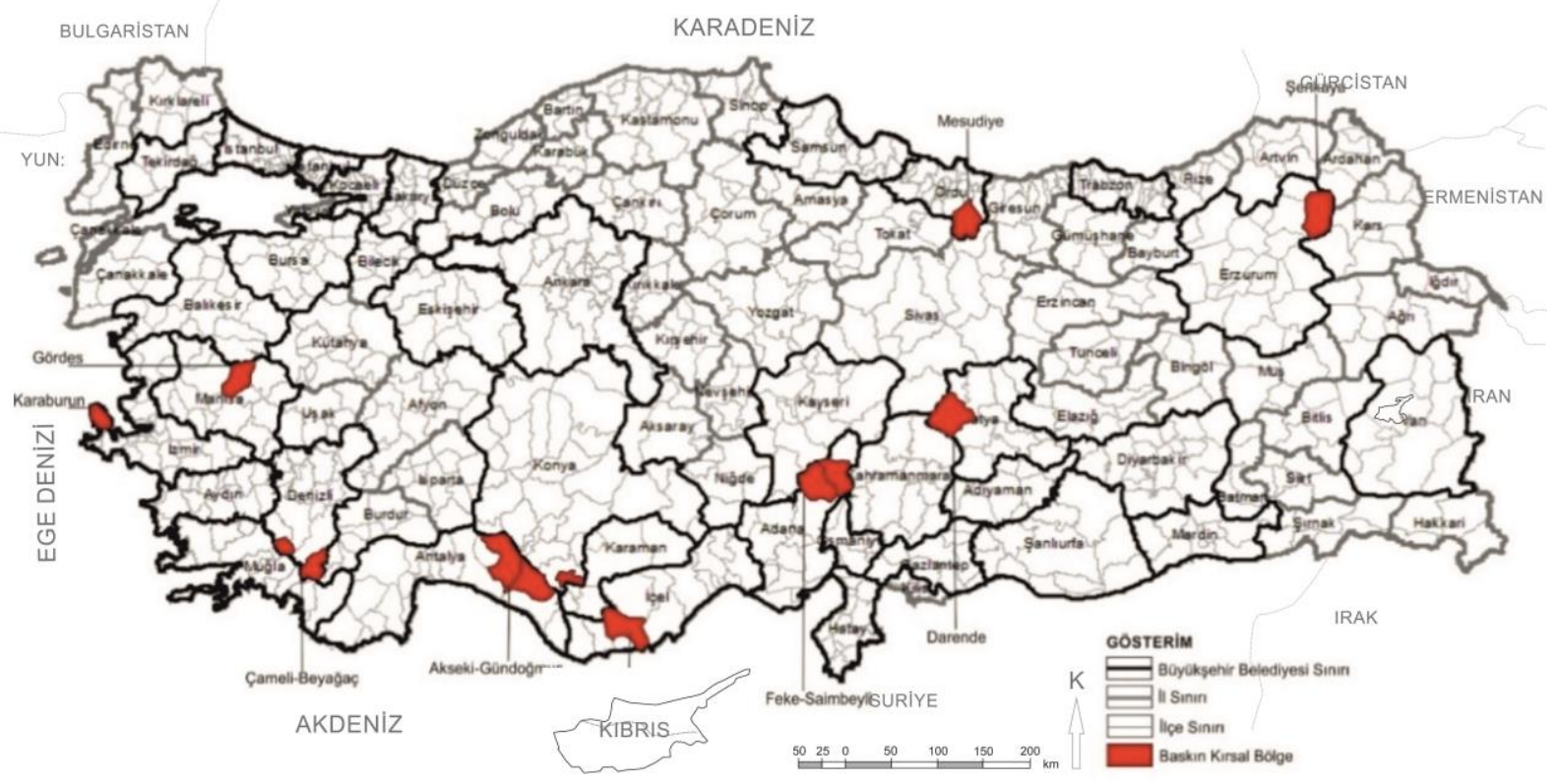

Şekil.11. Sentez:1. Baskın Kırsal Bölge Olarak Tespit Edilen İlçeler (Yazar Tarafından Hazırlanmıştır). 


\subsection{Sentez-2: Orta Düzey Kırsal Bölge}

Orta düzey kırsal bölgeleri tespit etmek amaciyla gerçekleştirilen ikinci sentezde, 1. Sentezde yapıldığ 1 gibi OECD'nin kırsal nüfus oranına göre yaptığ 1 kırsal tanımı ve tarımsal istihdam oranı, nüfus yoğunluğu, merkeze olan karayolu uzaklığ 1 verileri birlikte değerlendirilerek orta düzey kırsal ilçeler belirlenmiştir. Bu amaçla,

- Nüfusun $\% 15$ ve $\% 50$ arasındaki nüfusun kırsal nüfus olması (OECD siniflandirmasi),

- Tarımsal istihdam oranının \%5-\%15 aralığında olması,

- Nüfus yoğunluğunun $150 \mathrm{kişi} / \mathrm{km}^{2}$ altında olmasi,

- Merkeze uzaklığın 50-100 km aralığında olması,

Durumu, gösterilen aralıkları kapsayacak biçimde Arcmap ortamında ayrıştırılmıştır. Baskın kırsal bölge tespitinde uygulandığı gibi, orta düzey kırsal bölgelerin tespitinde de aynı yöntem uygulanmıştır.

Tarımsal istihdam verisi içerisinden \%5-\%15 aralığına sahip ilçeleri bulabilmek amacıyla ana menüde yer alan selection (seçim), sonrasinda select by attributes (özelliklerine göre seç) komutları kullanılmıştır. Açılan ekranda layer (katman) kısmında ilçe tarım dosyası; dosya içerisinde tarımda çalışan oranı seçilmiş daha sonra get unique values (özgün değerler elde et) komutu seçilerek $5=<$ tarımda çalışan oranı ve tarımda çalışan oranı $<15$ değeri girilmiştir. Verify (doğrula) komutu seçilerek veri doğrulanmıș apply (uygula) ve ok (tamam) komutları seçilerek işlem tamamlanmıştır. Bu işlem sonrasında, tarımsal istihdam oranı $\% 5$ ile $\% 14,9$ aralığında olan ilçeler seçilmiştir.

Seçilen ilçelerden ayrı bir katman oluşturabilmek amacıyla tarım katmanı üzerine sağ tıklanarak açılan pencerede selection (seçim) komutu, buradan açılan pencereden de create layer from selected features (seçilen özelliklerden katman oluştur) komutu seçilmiştir.

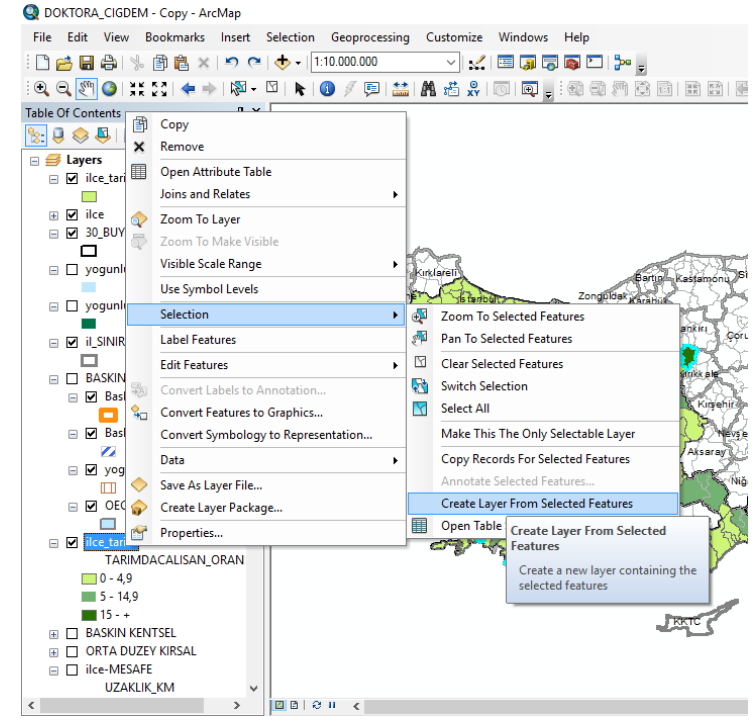

Şekil 12. Tarımsal istihdam oranı $\% 5$ ile $\% 14,9$ aralığında olan ilçelerden katman oluşturulması

$\mathrm{Bu}$ işlemler sonucunda $\% 5$ ile $\% 14,9$ aralığında tarımsal istihdam oranına sahip ilçeler diğerlerinden ayrıştırılarak bu ilçelerden yeni bir katman oluşturulmuştur.

Merkeze karayolu mesafesi değişkeninde de yukarıda izlenen yöntem izlenmiş ve $50 \mathrm{~km}$ $100 \mathrm{~km}$ aralığında karayolu mesafesi bulunan ilçeleri diğerlerinden ayırabilmek amaciyla ana menüde yer alan selection (seçim), sonrasında select by attributes (özelliklerine göre seç) komutları kullanılmıştır. Açılan ekranda layer (katman) kısmında ilçe mesafe dosyası; dosya içerisinde uzaklık km değeri seçilmiștir. Daha sonra get unique values (özgün değerler elde et) komutu seçilerek $50<=$ uzaklık $\mathrm{km}$ ve uzaklık $\mathrm{km}<100$ değeri girilmiştir. Verify (doğrula) komutu seçilerek veri doğrulanmış apply (uygula) ve ok (tamam) komutları ile işlem tamamlanmıştır (Şekil 13). 


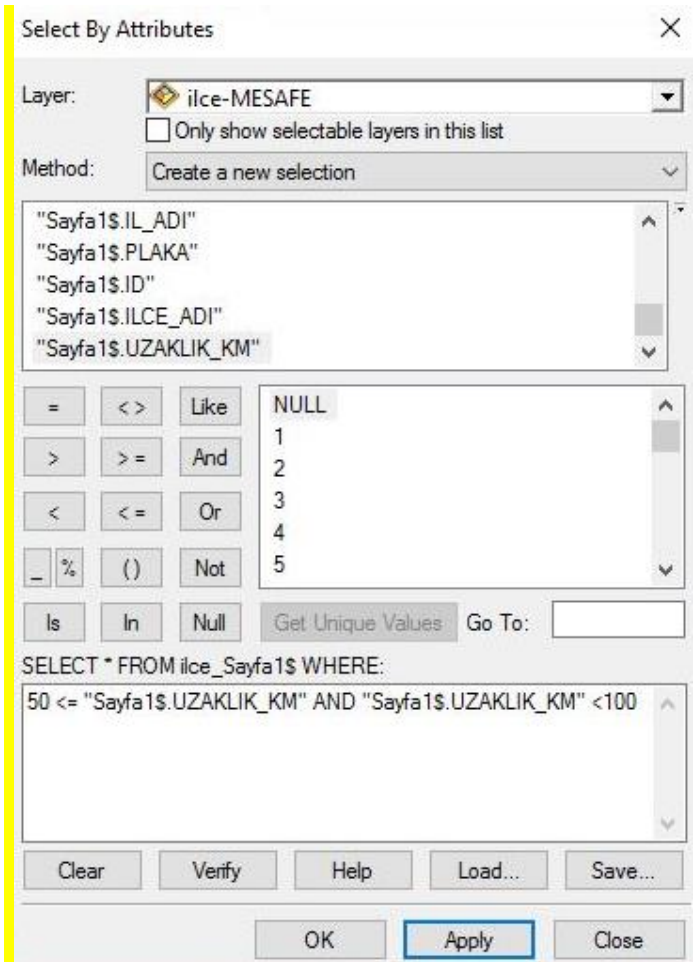

Şekil.13. Merkeze Karayolu Mesafesi Verisi Orta Düzey Kırsal Bölge Aralıklarının Oluşturulması

Bu aşamanın ardından, uzaklık katmanına sağ tıklanarak açılan pencerede selection (seçim) komutu, buradan açılan pencereden de create layer from selected features (seçilen özelliklerden katman oluştur) komutu seçilmiş ve $50 \mathrm{~km}$ ile $99,9 \mathrm{~km}$ aralığında merkeze karayolu mesafesi bulunan ilçelerden ayrı bir katman oluşturulmuştur. Bu iki değişken için takip edilen yöntem, kırsal nüfus oranı için de gerçekleştirilmiştir. Yine ana menüde yer alan selection (seçim), sonrasinda select by attributes (özelliklerine göre seç) butonları kullanılarak açılan ekranda layer (katman) kısmında ilgili dosyalar seçilmiştir. Daha sonra get unique values (özgün değerler elde et) komutu seçilerek $15<=$ kırsal nufus oranı ve kırsal nufus oranı $<50$ değeri girilmiştir.

Kırsal nüfus katmanına sağ tıklanarak açılan pencerede selection (seçim) komutu, buradan açılan pencereden create layer from selected features (seçilen özelliklerden katman oluştur) komutu seçilmiş ve \%15 ile \%49,9 aralığında kırsal nüfus oranına sahip ilçelerden ayrı bir katman oluşturulmuştur.

Son olarak aynı işlemler dördüncü değişken olan nüfus yoğunluğu için de uygulanmış; 150 $\mathrm{kişi} / \mathrm{km}^{2}$ altında olan nüfus yoğunluğuna sahip ilçeler belirlenmiştir.

Orta düzey kırsal bölge sentez haritasını oluşturmak için yukarıda sıralanan dört değişkenin ayrı ayrı yer aldığı katmanlar, yeni bir başlık altında (orta düzey kırsal bölge) toplanmıştır. Bu katmanlar ekranda aynı anda açılmış ve üst üste çakışmaları sağlanmıştır. Dört değişkenin de aynı anda bulunduğu ilçeler, orta düzey kırsal bölgeleri oluşturmaktadır.

Şekil 14'de de görüleceği gibi bu dört değişkenin de bir arada bulunduğu, tüm verilerin çakıştığı ve tez kapsamında orta düzey kırsal alan tanımlaması altına giren, 30 büyükşehir belediyesi genelinde toplam 11 ilçe bulunmaktadır.

2. Sentez kapsamına giren orta düzey kırsal bölge özelliği gösteren ilçeler şu şekilde siralanmaktadır:

Bursa: Karacabey, Yenişehir

İzmir: Tire

Manisa: Salihli

Aydın: Söke

Muğla: Dalaman

Samsun: Yakakent

Denizli: Güney

Adana: Kozan

Kayseri: Özvatan

Mardin: Midyat 


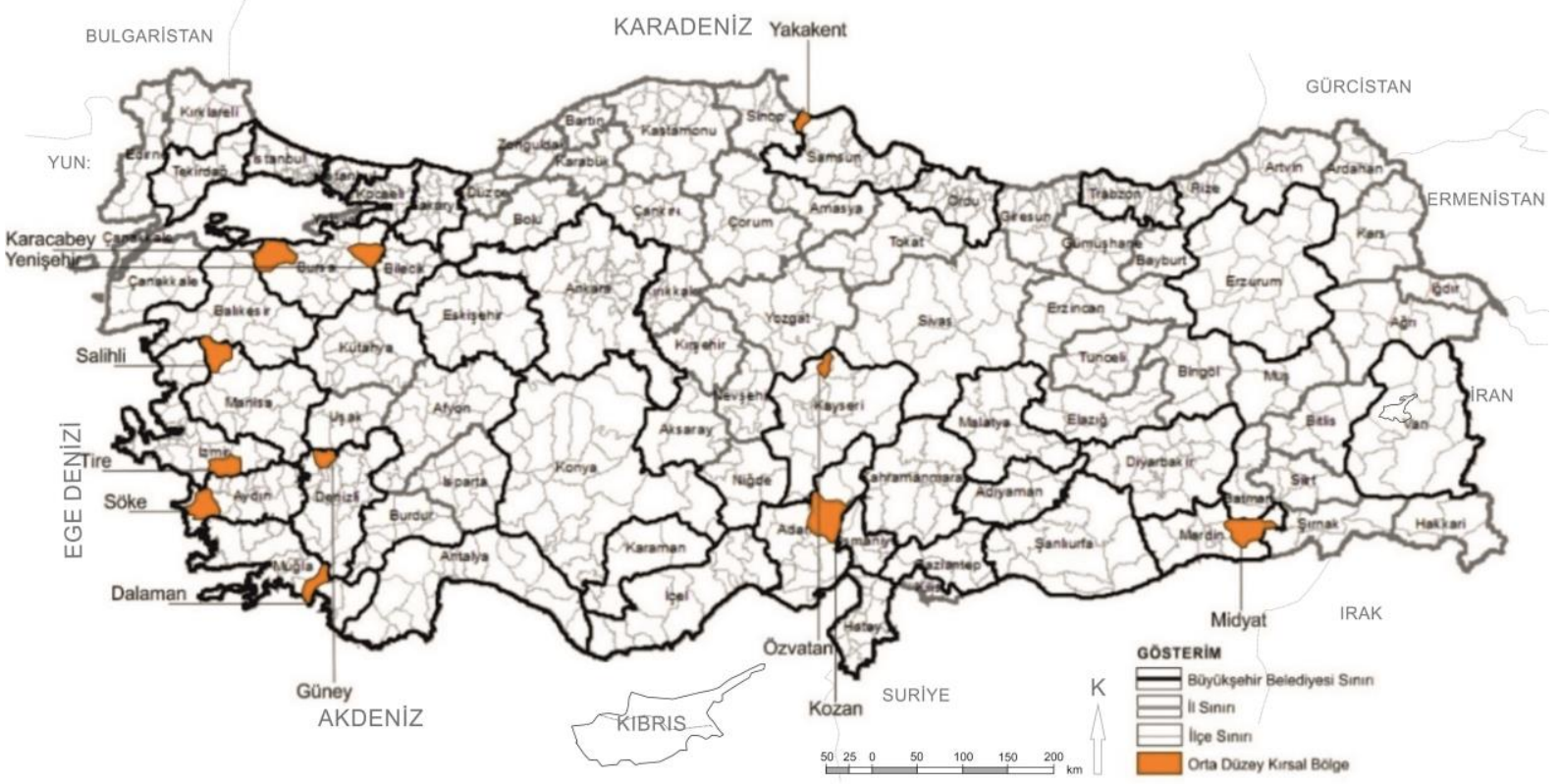

Şekil.14. Orta Düzey Kırsal Bölge Olarak Tespit Edilen İlçeler, (Yazar Tarafından Hazırlanmıştır).

\subsection{Sentez-3: Baskın Kentsel Bölge}

Üçüncü Sentez, ilk iki sentezin aksine, büyükşehirlerde yer alan kırsal alanları tespit etmek amaciyla değil, bu şehirlerde en fazla kentsel özellik gösteren yerleşimleri tespit etmek amaciyla gerçekleştirilmiştir. Bu sentez kapsamında da yine ilk iki sentezde değerlendirmeye alınan tarımsal istihdam oranı, nüfus yoğunluğu, OECD tanımına göre baskin kentsel alanlar ve merkeze olan karayolu mesafesi değişkenleri ele alınmış, ancak kentsellik düzeylerinin ölçülebilmesi için her bir değişkenin farklı aralıkları kullanılmıştır.

$\mathrm{Bu}$ analizde OECD'nin baskın kentsel bölge tanımında kullandığı $\% 15$ ve altı nüfusun kentsel olması kıstasına, Nüfus yoğunluğunun $150 \mathrm{kişi} / \mathrm{km}^{2}$ 'nin üzerinde olması, merkeze olan mesafenin $50 \mathrm{~km}$ altında olması, tarımsal istihdam oranının $0-\% 5$ arasında olmas1 değişkenleri eklenerek sonuca ulaşılmıştır.

Yukarıda sıralanan dört değişkeni, Arcmap ortamında mekânsallaştırılabilmek için her bir değişken, baskın kentsel bölgeleri tespit etmeye yönelik oluşturulan aralıklara göre ayrıştırılmıştır.

Tarımsal istihdam verisinde kullanılan üç kategoriden $\% 5$ 'in altında tarımsal istihdam oranına sahip ilçeleri seçebilmek amacıyla, ana menüde yer alan selection (seçim), sonrasında select by attributes (özelliklerine göre seç) komutları kullanılmıştır. Açılan ekranda layer (katman) kısmında ilçe tarım dosyası; dosya içerisinde tarımda çalışan oranı seçilmiş daha sonra get unique values (özgün değerler elde et) komutu seçilerek $<5$ değeri girilmiştir. Verify (doğrula) komutu seçilerek veri doğrulanmış, apply (uygula) ve ok (tamam) komutları seçilerek işlem tamamlanmıştır.

$\mathrm{Bu}$ işlem sonrasında, tarımsal istihdam oranı $\% 5$ 'ten az olan ilçeler seçilmiştir. Daha sonra, ilçe tarım katmanı üzerine sağ tıklanarak açılan pencerede selection (seçim) komutu, buradan açılan pencereden de create layer from selected features (seçilen özelliklerden katman oluştur) komutu seçilmiştir. Yapılan bu işlemler neticesinde tarımsal istihdam oran $1 \% 5$ 'ten daha az olan ilçelerden ayrı bir katman oluşturulmuştur (Şekil 15) 


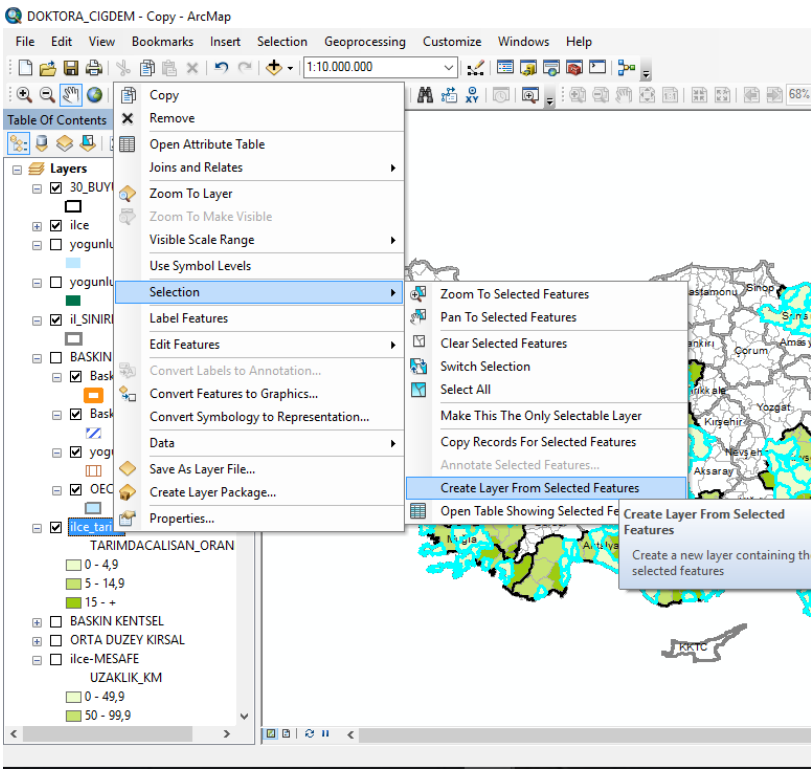

Şekil.15. Tarımsal istihdam oran1 $\% 5$ 'ten az olan ilçelerden katman oluşturulması

Tarımsal istihdamda olduğu gibi, merkeze karayolu mesafesi için de kategorize edilen üç farklı uzaklık birimi için baskın kentsel bölgeye uyumlu olan $50 \mathrm{~km}$ 'den yakın olma durumunu çekebilmek amaciyla ana menüde yer alan selection (seçim), sonrasında select by attributes (özelliklerine göre seç) komutları kullanılmıştır. Açılan ekranda layer (katman) kısmında ilçe mesafe dosyası; dosya içerisinde uzaklık km değeri seçilmiştir. Daha sonra get unique values (özgün değerler elde et) komutu seçilerek $<50$ girilmiştir. Verify (doğrula) komutu seçilerek veri doğrulanmış apply (uygula) ve ok (tamam) komutları seçilerek işlem tamamlanmıştır. Bu işlem sonrasında, merkeze karayolu mesafesi $50 \mathrm{~km}$ altında kalan ilçeler belirlenmiştir.

Uzaklık katmanına sağ tıklanarak açılan pencerede selection (seçim) butonu, buradan açılan pencereden de create layer from selected features (seçilen özelliklerden katman oluştur) komut seçilmiş ve $50 \mathrm{~km}$ altında merkeze karayolu mesafesine sahip ilçelerden ayrı bir katman oluşturulmuştur.

$\mathrm{Bu}$ iki değişken için takip edilen yöntem, OECD sinıflandırmasına göre kırsal nüfus oranı ve nüfus yoğunluğu değişkenleri için de uygulanmıştır. $\mathrm{Bu}$ işlemler için de ana menüde yer alan selection (seçim), sonrasında select by attributes (özelliklerine göre seç) komutları kullanılarak ekranda açılan ekranda layer (katman) kısmında ilgili dosyalar seçilmiş̧ir. Takibinde get unique values (özgün değerler elde et) komutu seçilerek kırsal nüfus oranı için kırsal nufus oranı $<15$ değeri girilerek doğrulama işlemi gerçekleştirilmiştir. Bu işlem sonrasında, kırsal nüfus oran $1 \% 15$ altında olan ilçeler seçilmiştir.

Ana menüde kırsal nüfus oranı katmanına sağ tıklanarak açılan pencerede selection (seçim) komutu, buradan açılan pencereden de create layer from selected features (seçilen özelliklerden katman oluştur) komutu seçilmiş ve $\% 15$ altında kırsal nüfus oranına sahip ilçelerden ayrı bir katman oluşturulmuştur.

Nüfus yoğunluğu verisi için de ana menüde yer alan selection (seçim), sonrasında select by attributes (özelliklerine göre seç) komutları kullanılarak açılan ekranda nüfus yogunlugu $>=150 \mathrm{kişi} / \mathrm{km}^{2}$ değerleri girilmiş ve önceki bölümlerde olduğu gibi doğrulama işlemi tamamlanmıştır. $\mathrm{Bu}$ işlem sonrası nüfus yoğunluğu $150 \mathrm{kişi} / \mathrm{km}^{2}$ üzerinde olan ilçeler seçili hale gelmiştir.

Seçili ilçelerden ayrı bir katman oluşturmak üzere yine önceki bölümlerde olduğu gibi ana menüde nüfus yoğunluğu katmanına sağ tıklanarak açılan pencerede selection (seçim) butonu, buradan açılan pencereden de create layer from selected features (seçilen özelliklerden katman oluştur) komutu seçilmiştir. $150 \mathrm{kişi} / \mathrm{km}^{2}$ nüfus yoğunluğu üzerinde olan ilçelerden ayrı bir katman oluşturulmuştur.

Baskın kentsel bölge sentez haritasını oluşturmak için yukarıda sıralanan dört değişkenin ayrı ayrı yer aldığı katmanlar, yeni bir başlık altında toplanmıştır. Bu katmanlar ekranda aynı anda açılmış ve üst üste çakışmaları sağlanmıştır. Her bir değişkenin üst üste çakıştığı ilçe, baskın kentsel bölgeyi oluşturmaktadır. Bu işlemler sonucunda Şekil 16 oluşturulmuştur. 


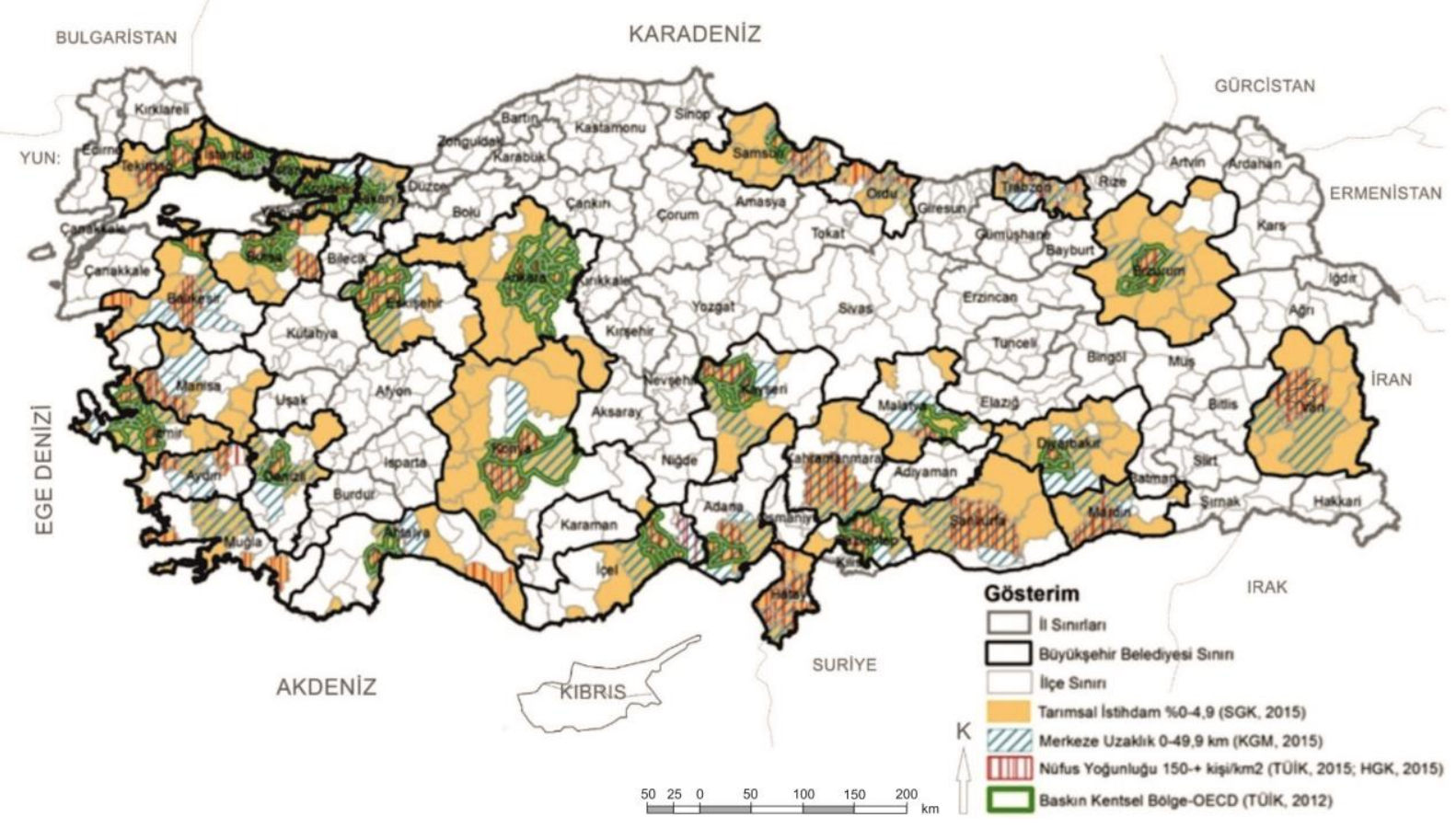

Şekil.16. Baskın Kentsel Bölge Olarak Tespit Edilen İlçeler, (Yazar Tarafindan Hazırlanmıştır).

\section{SONUCCLAR ve TARTIȘMA}

Bu çalışmada, 30 büyükşehir belediyesinde, ilçeler düzeyinde kırsal karakterin nasıl bulunacağı, sınıflandırmanın neye göre ve nasıl yapılacağı coğrafi bilgi sistemleri (CBS) kullanılarak ortaya konmuştur.

$\mathrm{Bu}$ çalışmada, ilçelere göre nüfus yoğunluğu (TUíK, 2015), kısal nüfusun toplam nüfusa oranı (TUIK, 2012), ilçelerin kent merkezine kara yolu uzaklığı (KGM, 2015), tarımsal istihdam oranı (SGK, 2015) değişkenleri kullanılmıştır. Değişkenlerin, coğrafi bilgi sistemleri ortamında analiz edilebilmesi için, illere ve ilçelere dair veri tabanının yer aldığı Arc Map haritasılyla eşleştirilmiş, veriler sayısallaştırılmış ve mekânsallaştırılmıştır. Veriler CBS kullanılarak haritalara işlenerek izobarlarla kırsallığın kademeleri ortaya çıkarılmıştır. Bu işlem sonucunda öncelikle her bir değişkenin ayrı ayrı ele alındığı analiz haritaları üretilmiş; sonrasında ise tüm bu haritaların belirli sınıflandırmalarla üst üste çakışmasından elde edilen sentez haritalar elde edilmiştir. Çalışma sonucunda baskıı kırsal bölge, orta düzey kırsal bölge ve baskın kentsel bölge olmak üzere toplam üç adet sentez harita üretilmiş, bu kategorilerde yer alan ilçeler tespit edilmiştir.

1. Sentez olan baskın kırsal bölgeler kapsamında kırsal niteliklerini devam ettirmekte olan 13 ilçe: Manisa Gördesİzmir Karaburun- Denizli Çameli, Beyağaç- Antalya Akseki, GündoğmuşKonya Taşkent- Mersin Gülnar- Adana Feke, Saimbeyli- Malatya DarendeErzurum Şenyayla- Ordu Mesudiye;

2. Sentez olan orta düzey kırsal bölgeler kapsamında ise kırsal niteliklerini devam ettirmekte olan 11 ilçe: Bursa Karacabey, Yenişehir- İzmir Tire- Manisa SalihliAydın Söke-Muğla Dalaman-Samsun Yakakent- Denizli Güney- Adana Kozan, Kayseri Özvatan, Mardin Midyat;

3. Sentez kapsamında ise, özellikle büyükşehir belediyelerinin merkez ve merkezin çeperinde yer alan ilçelerin baskın kentsel bölge niteliği gösterdiği;

Tespit edilmiştir. 


\section{KAYNAKÇA}

$\mathrm{Bu}$ araştırma ile 30 büyükşehir belediyesinin her bir alanının birbiriyle aynı özellikler göstermediği, dolayısıyla büyükşehirlerde yer alan her bir yerleşimin kent statüsünde bulunmaması gerektiği; yerleşimlerin farklılıklarının sistematik bir biçimde tespit edilmesi ve sınıflandırılması gerektiği ortaya konmuştur.

Bu çalışma, Türk planlama sistematiği içinde, önümüzdeki dönemde eksikliği çok daha fazla hissedilecek olan, metropoliten gelişme alanlarında kırsal alan siniflandırmasının nasıl olması gerektiğini ortaya koymakta, literatüre, yasa ve yönetmelikler ile pratikteki uygulamalara katkıda bulunmaktadır.

İlerleyen aşamalarda ise:

- $\mathrm{Bu}$ araştırmada izlenen yöntem kullanılarak aynı ya da benzer değişkenlerle bu çalışma mahalle düzeyinde tekrarlanabilir. Böylece il sınırları dâhilinde her bir mahallenin karakter farklılıkları ortaya konarak bu karakter farklıliklarına yönelik planlama çalışmaları yapılabilir.

- Çalışmada görüldüğü üzere büyükşehir belediyeleri içerisinde kırsal karakterleri ile öne çıkan ilçeler yer almaktadır. Dolayısıyla bu çalışmadan yola çıkarak her bir karakter alanın kendi koşullarına uygun planlama çalışmaları ve planlama araçları geliştirilebilir.

- Elde edilen bu tespitle birlikte ilerleyen aşamalarda, baskın kırsal ve orta düzey kırsal bölgelerde kırsal faaliyetlerin ve kırsal üretimin devamlılığını ve bu alanların kendine özgü karakterlerini sürdürmelerini sağlamak için çevresel, mekânsal ve sosyo-ekonomik anlamda neler yapılabileceği ortaya konabilir.
Agapiou, A., Lysandrou, V., Alexakis, D. D.,Themistocleous, K., Cuca, B., Argyriou, A.,Sarris, A. ve Hadjimitsis, D. G., (2015). Culturalheritage management and monitoring usingremote sensing data and GIS: The case study ofPaphos area, Cyprus, Computers, Environmentand Urban Systems, 54, 230-239.

Adrese Dayalı Nüfus Kayıt Sistemi (ADNKS), 2015, URL:

http://www.webcitation.org/query?url=http $\% 3 \mathrm{~A} \% 2 \mathrm{~F} \% 2 \mathrm{Fwww}$.tuik.gov.tr\%2FPreTablo .do\%3Falt_id\%3D1047\&date=2017-10-02, Son Erişim Tarihi: 10.08.2016

Aydal, D. (2012). Uzaktan Algilama ve Coğrafi Bilgi Sistemi Tekniklerinin Jeoloji, Madencilik, Çevre Araştirmalarinda ve İnşaat Sektöründe Kullanilma Örnekleri. URL:http://www.doganaydal.com/nesneler/ uzaktanalgilama.pdf, Son Erişim Tarihi: 06.11 .2017

Drucker, J. (2012). Humanistic theory and digital scholarship. University of Minnosota Press: Minnosota, 85-95.

Elwood, S. (2010). Geographic information science: Emerging research on the societal implications of the geospatial web. Progress in Human Geography, 34, 349-357.

Gıda Tarım ve Hayvancılık Bakanlığı. (2015). Ulusal kırsal kalkinma stratejisi 2014-2020. Ankara: Gida Tarım ve Hayvancillk Bakanlığ 1 , 24-66.

Kalkınma Bakanlı̆̆ı. (2013). Onuncu kalkınma planı (2014-2018). Ankara. 60-65.

Organisation for Economic Cooperation and Development. (2006). The new rural paradigm, policies and governance. Paris: OECD Publishing, Paris, 15-26.

Özyavuz, M. (2011). Tekirdağ Kent Merkezinin Zamansal Değişiminin Uzaktan Algılama ile İncelenmesi. Tekirda $\breve{g}$ Ziraat Fakültesi Dergisi, 65.

Yomralığlu, T. (2009). Coğrafi Bilgi Sistemleri temel kavramlar ve uygulamalar, Trabzon: Akademi Kitapevi. 
6360 Sayılı On Dört İlde Büyükșehir Belediyesi ve Yirmi Altı İlçe Kurulması ile Bazı Kanun ve Kanun Hükmünde Kararnamelerde Değişiklik Yapılmasina Dair Kanun, 2012, Md. 1-3-5-6-714-15-16-24, URL:

http://www.webcitation.org/query?url=http $\% 3 \mathrm{~A} \% 2 \mathrm{~F} \% 2 \mathrm{~F} \% 3 \mathrm{~A}+\mathrm{https} \% 3 \mathrm{~A} \% 2 \mathrm{~F} \% 2 \mathrm{Fww}$ w.tbmm.gov.tr\%2Fkanunlar\%2Fk6360.html \&date=2017-10-02, Son Erişim Tarihi:

06.10 .2016 